\title{
Grey seal diet analysis in Ireland highlights the importance of using multiple diagnostic features
}

\author{
M. Gosch ${ }^{1,2, *}$, G. Hernandez-Milian' ${ }^{2}$, E. $\operatorname{Rogan}^{2}{ }^{2}$ M. Jessopp ${ }^{1}$, M. Cronin ${ }^{1}$ \\ ${ }^{1}$ Coastal \& Marine Research Centre, University College Cork, Ireland \\ ${ }^{2}$ School of Biological, Earth and Environmental Science, University College Cork, Ireland
}

\begin{abstract}
Seals and humans are top predators in many marine ecosystems, often targeting the same food resource. With global declines in fish stocks, competition between these top predators is of increasing interest to scientists and resource managers. To understand and quantify this competition, robust data on the diet of seals are necessary. We present new information on the diet of grey seals Halichoerus grypus from a colony on Great Blasket Island, southwest Ireland, with particular reference to commercially important prey species such as salmonids. Inter-annual variation in diet was investigated based on the recovery and identification of sagittal fish otoliths, bones and cephalopod beaks from faecal samples collected in 2009 and 2010. A total of 939 prey items were recovered, representing a minimum of 41 prey species. Thirty species were identified from otoliths while a further 11 species, including salmonids, were identified from additional diagnostic structures. The diet of grey seals was largely dominated by Gadiformes ( $21 \%$ corrected biomass), particularly Trisopterus spp., which contributed $7 \%$ in terms of corrected biomass and $52 \%$ by frequency of occurrence, while salmonids comprised over $36 \%$ of diet by corrected biomass. Inter-annual variation in sandeel (Ammodytidae) and blue whiting Micromesistius poutassou abundance was apparent, while the former was an important contributor to the diet in terms of corrected biomass $(11 \%)$. The results support the principle that an 'all structures' approach to pinniped diet estimation can significantly increase the rate of detection for most fish groups, and result in improved estimation of seal diet.
\end{abstract}

KEY WORDS: Grey seal $\cdot$ Diet $\cdot$ Scats $\cdot$ Fisheries $\cdot$ Salmonids $\cdot$ Biomass

Resale or republication not permitted without written consent of the publisher

\section{INTRODUCTION}

The waters off the west and southwest coast of Ireland are recognised as one of the most biologically productive regions in the eastern North Atlantic Ocean (ICES 2003). These regions provide ideal spawning and nursery grounds for many fish species and are particularly important for anadromous salmonids such as sea trout Salmo trutta and Atlantic salmon Salmo salar. Wild salmon stocks in Irish waters have been declining rapidly due to factors such as water pollution/habitat degradation, predation, drift-netting and overfishing (Brennan \& Rodwell 2008). Sea trout numbers have also experienced a significant decline over the last 4 decades, particularly in the numbers of migrating smolts (Byrne et al. 2004). As salmon are afforded Annex II status under the EU Habitats Directive (in respect to their freshwater habitat), a ban on inshore drift-net fishery was introduced in Ireland in 2006, and strict catch and release limits have been introduced for recreational fisheries in estuaries where salmon stocks are below conservation limits (Inland Fisheries Ireland 2012). Despite the drift-net ban and other conservation measures, salmon stocks have still not recovered in many areas, and it has been suggested that seal predation may be preventing salmon stocks from recovering (Brennan \& Rodwell 2008). The impact seals 
may be having on salmon and sea trout stocks is poorly understood due to the difficulties in assessing predation levels from dietary studies and visual observations, along with complications that arise from the predators' interactions with other prey species, and vice versa (Pierce et al. 1990, Carter et al. 2001, Parsons et al. 2005). In Scotland, seals have been observed preying on migrating salmonids in rivers and estuaries (Butler et al. 2011) and can cause extensive damage to coastal nets and salmon farms (Butler et al. 2008). Qualitative information obtained from the Irish aquaculture industry suggests substantial losses of salmon to seal predation (up to $20 \%$ of the harvest at some sites), and seal damage to salmon in the rod and line and snap net salmon fisheries was estimated to be as high as $40 \%$ in some regions on the western seaboard of Ireland (Cronin et al. 2010).

The most recent population data available for grey seals Halichoerus grypus in Ireland provides a breeding population estimate of 5509 to 7083 individuals (Ó Cadhla et al. 2007). From studies across the species' range, grey seals are considered to be opportunistic, generalist predators, consuming a wide variety of demersal and small pelagic fish (Austin et al. 2006), and can display both regional and seasonal variation in their diet (Hammond et al. 1994, McConnell et al. 1999, Breed et al. 2006, Beck et al. 2007). Unfortunately, research conducted on grey seal diet in Ireland is limited to a few studies in the 1990s (Cronin et al. 2010). Furthermore, while both the Irish salmon aquaculture industry as well as rod and line fisheries in certain rivers/estuaries report substantial seal-related losses, particularly on the west coast (Cronin et al. 2010), no evidence of salmonid remains have been identified in the diet of grey seals prior to this study, although salmonids have been recorded in the diet of harbour seals (Kavanagh et al. 2010).

Assessment of marine mammal diet is typically carried out through the identification and counting of fish otoliths and cephalopod beaks recovered from predator gut contents and/or scat (faecal) samples (Pierce et al. 1993). Identification and quantification of prey items can prove problematic, however, if the predator is a generalist - consuming a wide range of prey species. Those species with fragile otoliths and bones (e.g. clupeids and salmonids) may often go undetected, while those with more robust structures (e.g. gadoids) may be over-represented in the diet (Tollit et al. 1997, Grellier \& Hammond 2005). Furthermore, sole reliance on otoliths may reduce the range of species detected, as species such as cartilaginous fish lack distinct otoliths and therefore can often go undetected, leading to their presence being significantly underestimated within the predators' diet (Pierce et al. 1993). To overcome this problem, the use of other hard diagnostic structures such as jaw bones, denticles, and scales are increasingly being used in dietary studies to improve species detection (Pierce \& Boyle 1991, Pierce et al. 1993). The identification of diagnostic structures apart from otoliths has been demonstrated to minimize the bias in fish prey detection as well as improve the quantitative estimation of the diet; for example, $55 \%$ of fish prey were identified using hard parts other than otoliths in harbour seal scats (Cottrell et al. 1996), and Olesiuk et al. (1990) reported that only $42 \%$ of fish prey found in harbour seal scats were identified solely from otoliths.

In this study, we investigated the diet of grey seals from a colony of national importance in southwest Ireland. The contribution of prey species to the diet of grey seals was examined through the analysis of scat samples, and inter-annual differences in diet were explored. In order to achieve an accurate representation of grey seal diet, we used the 'all structures' method to increase the probability of prey species detection. The resulting information will contribute to our understanding of the impact of seals on commercial species, such as salmonids and whiting Merlangius merlangus, in southwest Irish waters.

\section{MATERIALS AND METHODS}

\section{Study site and scat collection}

The Blasket Islands consist of 15 islands, located 1.5 to $12 \mathrm{~km}$ west of the Dingle Peninsula, Co. Kerry in southwest Ireland. Among these, the Great Blasket Island $\left(10^{\circ} 30^{\prime} 53^{\prime \prime} \mathrm{W}, 52^{\circ} 06^{\prime} 15^{\prime \prime} \mathrm{N}\right)$ is the largest uninhabited island and one of the most important moulting sites for grey seals in Ireland. The site supports a mixed haul-out group by both age and sex. During the moult period (December to April), up to 1000 individuals have been observed on An Trá Bán, a broad sandy beach on the northwest of the island (Fig. 1). These numbers account for almost $20 \%$ of the national moult population (Ó Cadhla \& Strong 2007). Scats were collected from this site during spring months (February and April) in 2009 and 2010, when weather permitted access by boat. Sample numbers for 2009 totalled 83, while 53 scats were collected in 2010. All samples were stored in separate polythene bags, labelled, and frozen at $-20^{\circ} \mathrm{C}$ until processing. 


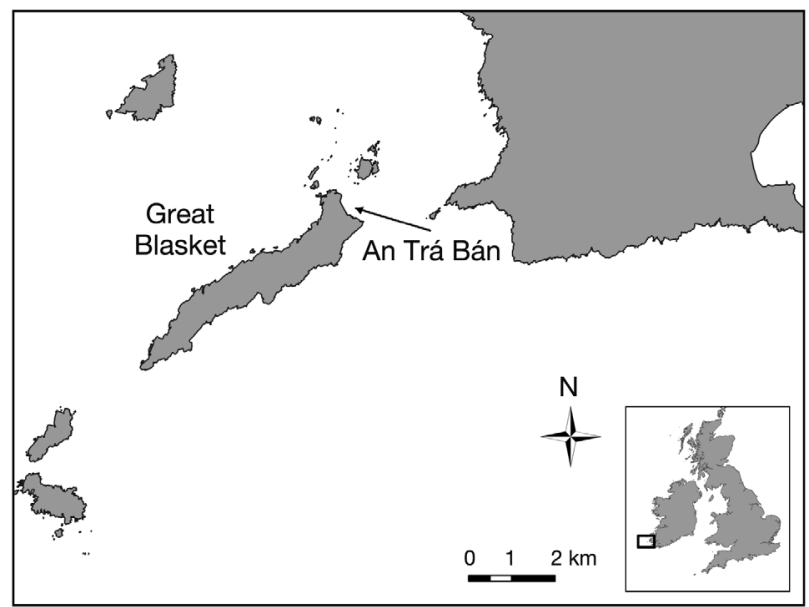

Fig. 1. Sampling site: An Trá Bán, located on the Great Blasket Island, Co. Kerry, Ireland

\section{Dietary analysis}

Samples were washed through a nest of sieves with a maximum mesh size of $5 \mathrm{~mm}$ and a minimum mesh size of $0.25 \mathrm{~mm}$. All prey remains recovered (cephalopod beaks, otoliths and skeletal parts) were transferred into $70 \%$ ethanol for sterilization and subsequently stored pending identification. Prey items were measured using an eyepiece graticule fitted to a Zeiss 200S binocular dissecting microscope at $40 \times$ magnification for prey remains smaller than $1 \mathrm{~cm}$, and digital callipers (accuracy $\pm 0.01 \mathrm{~mm}$ ) for remains greater than $1 \mathrm{~cm}$. Reference collections and published guides (e.g. Clarke 1986, Härkönen 1986, Watt et al. 1997, Tuset et al. 2008) were used to identify cephalopod beaks, fish otoliths and fish bones to their lowest possible taxonomic level. When it was not possible to identify to specific taxonomic level due to the degree of erosion, prey items were grouped into genus (e.g. Trisopterus spp., Salmo spp., Pollachius spp.). Sandeels were grouped as family Ammodytidae due to the difficulty in distinguishing between species. Highly eroded items were considered secondary items and excluded from further analysis (following Pierce \& Boyle 1991), including fish/ cephalopod eye lenses and crustacean remains. Cephalopod length and biomass was reconstructed from recovered beaks using published regression equations (Clarke 1986, Pierce et al. 1993), while fish length and mass were reconstructed from otolith, premaxilla and vertebra bones using published regression equations (see Table S1 in the Supplement at www.int-res.com/articles/suppl/b020p171_ supp.pdf). Measurements of other skeletal structures (e.g. dentaries, maxillae and preopercula) were taken, however, back-calculation regressions were not available in most cases and therefore genus/ family regression was applied, or average length of the species was used from FishBase 2011 (Froese \& Pauly 2013). In order to account for partial erosion, digestion coefficients (DC) were applied as multipliers to otolith/squid beak lengths and numerical correction factors (NCF) were used to account for complete erosion of prey remains during the digestion process following Tollit et al. (1997), Grellier \& Hammond (2006), and Tollit et al. (2007) (Table S2 in the Supplement). The NCF were applied as a multiplier to the reconstructed, uncorrected mass of each prey item before the overall biomass was calculated for each species/taxa. When no species-specific DC were available for otoliths, an average correction factor from Tollit et al. (1997) was used. Unfortunately, no DC were available for octopus beaks, salmonid premaxillae and those species identified from bones alone. However, a NCF for Pacific salmon bones was available (Tollit et al. 2007) and was applied to salmonid premaxillae.

\section{Diet quantification}

In order to quantify the contribution of different prey species to grey seal diet, a number of methods were used. The minimum number of prey present was determined by counting the highest number of left or right otoliths, and upper or lower beaks. Some fish otoliths are delicate and rarely appear in seal scats, or they appear broken. However, bones of these species may resist the effects of digestion. Where possible, all fish bones (i.e. premaxillae, vertebrae, urohyals) were identified; they were then counted to obtain the minimum number of prey (e.g. urohyals are single bones and represent 1 prey item, premaxillae are paired bones and only the maximum number of left or right were considered). Vertebrae were visually examined and measured under a microscope. Those vertebrae from the same species but with differences in size of $\pm 1 \mathrm{~mm}$ were assumed to come from different individuals. This was done to prevent those fish which were represented by many vertebrae from dominating the diet. Occasionally bones and otoliths from the same species were found within the same sample; in these cases, if the total length of the fish reconstructed from the bone was similar to that derived from the otolith $( \pm 1 \mathrm{~mm})$, it was assumed that they belonged to the same prey and only the otolith was considered. 


\section{Prey selectivity and feeding strategy}

Percentage frequency of occurrence $(\% \mathrm{~F})$, percentage by number $(\% \mathrm{~N})$, and percentage by biomass $(\% \mathrm{~B})$ were used to express overall diet composition. $\% \mathrm{~N}$ is the number of times a prey species occurs expressed as a percentage of the total number of times all prey species occurred. \%F is the number of samples containing a certain prey species expressed as a percentage of all samples containing prey (Kavanagh et al. 2010).

Variability in predator feeding strategy and prey importance was visually examined using a modified version of the Costello (1990) graph following the interpretation outlined in Amundsen et al. (1996). The analysis is based on a 2-dimensional graph where prey-specific abundance or prey-specific biomass is plotted against the frequency of occurrence for the same prey (Amundsen et al. 1996). Prey-specific abundance is expressed as:

$$
\mathrm{P}_{\mathrm{i}}=\left(\sum \mathrm{S}_{\mathrm{i}} / \sum \mathrm{S}_{\mathrm{ti}}\right) \times 100
$$

where $P_{i}$ is the prey-specific abundance/biomass of prey $i_{1} S_{i}$ is the contribution of prey $i$ to the scat content, and $\mathrm{S}_{\mathrm{ti}}$ is the total scat content in only those samples where prey $i$ is present. Frequency of occurrence (as opposed to percentage frequency of occurrence) is expressed as:

$$
\mathrm{F}_{\mathrm{i}}=\mathrm{N}_{\mathrm{i}} / \mathrm{N}
$$

where $N_{i}$ is the number of scat samples containing prey $\mathrm{i}$ and $\mathrm{N}$ is the total number of scat samples containing prey.

\section{Inter-annual variation in seal diet}

In order to investigate the relationship between diet samples collected during spring in different sampling years, species abundances and biomass (both with and without NCF) were used to create a BrayCurtis similarity matrix. Bray-Curtis similarity is an index of how alike each sample is to all others based on the species abundances/biomass present in samples on a scale from 0 to 1 , where 0 indicates samples which are completely different (entirely different species present in samples) and 1 indicates samples which are identical (the same species in the same abundances). A square-root transformation was used to reduce the influence of numerically dominant species, and allow less abundant but potentially larger fish species that contribute greatly to overall biomass to influence the similarity between samples. Two- dimensional non-metric multidimensional scaling (nMDS) plots were used to visualize the multivariate patterns of assemblages (Clarke \& Warwick 2001). Permutational multivariate analysis of variance (PERMANOVA+) was used to test for differences in diet between years (Anderson et al. 2008). The SIMPER routine in PRIMER 6 statistical software (PRIMER 6, Plymouth Marine Laboratory) was then used to determine which species contributed the greatest dissimilarity between years to highlight differences in the abundance and biomass of certain prey species occurring over time.

\section{RESULTS}

\section{Overall prey abundance}

A total of 136 scat samples were processed, with 132 samples containing 939 identifiable prey items. Samples were collected in February 2009 ( $\mathrm{n}=57)$, February $2010(\mathrm{n}=40)$, April $2009(\mathrm{n}=26)$ and April 2010 ( $\mathrm{n}=13)$. A species accumulation curve was computed by random selection of sample data and permuted 999 times to account for any spatio-temporal heterogeneity due to the order in which samples were processed or selected. Fig. 2 shows a levelling off of the accumulation curve after 75 samples with very few additional species being found thereafter.

A total of 602 otoliths representing 30 taxa were recovered, of which $99.5 \%$ were identifiable to at least family level. The remaining $0.5 \%$ of otoliths were too eroded, and thus were taken to be second-

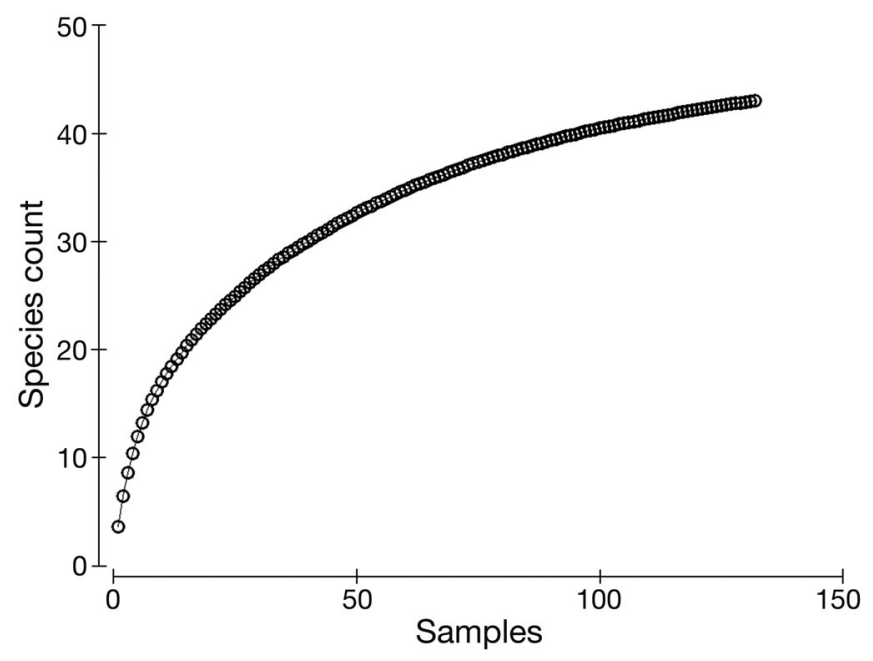

Fig. 2. Species accumulative curve plotting the total number of samples collected against the number of prey species found within seal scats 
ary prey items and excluded from further analysis. A further 11 taxa (37\% of prey identified) were detected by using other bones such as the premaxillae, preopercula and spines. When prey was considered combining otoliths and other hard structures, dragonets and non-identified fish increased by $335.7 \%$ and $368.8 \%$, respectively; flatfish identification also increased by $180.0 \%$ and gadoids by $41.6 \%$. In contrast, sandeels only increased by $17.3 \%$, while salmonids were identified solely from premaxillae and vertebrae.

When both sampling years were combined, teleost fish comprised the main prey grouping within the diet, representing $98 \%$ by number $(98 \% \mathrm{~N})$ of all prey items consumed. Other groups found within the diet included cephalopods, lampreys Petromyzon marinus and rays Raja spp.; however, collectively these only comprised $2 \% \mathrm{~N}$ of the entire diet. Overall, sandeels were numerically the most important prey species in the diet $(31 \% \mathrm{~N})$ and were found in $38 \%$ of all scats. Trisopterus spp. represented the second most numerically important prey in the diet $(21 \% \mathrm{~N})$, occurring in $51 \%$ of all samples. However, when both sampling years were viewed separately, Trisopterus spp. became the most numerically important $(27 \% \mathrm{~N})$ and most frequently occurring $(51 \% \mathrm{~F})$ prey in 2009, while sandeels remained numerically dominant $(50 \% \mathrm{~N})$ in 2010 , occurring in $65 \%$ of samples (Table 1). When sandeels were not present in the diet, there was an increased reliance on dragonets Callionymus spp. and other unidentified fish species. Blue whiting Micromesistius poutassou also appeared to contribute to a greater proportion of the seal diet in 2010, while salmonid abundance was slightly higher in 2009. Other frequently occurring taxa included unidentified gadoids and whiting.

\section{Prey length and biomass reconstruction}

Prey biomass was reconstructed from uncorrected mass for all prey species for which regression equations were available (Table 1). Squid and teleost fish lengths and biomass were reconstructed with and without the application of DC (Table 2). No correction factors were available for those species identified solely from bones (e.g. salmonids and Octopus spp., $\mathrm{n}=387$ ). With the exception of squid, prey length increased substantially after the application of DC. The use of DC increased mean fish length from $16.9 \mathrm{~cm}( \pm 7.4 \mathrm{SE})$ to $24.6 \mathrm{~cm}( \pm 12.1 \mathrm{SE})$, thus displaying an overall average increase of $46 \%$. Commercially important species such as whiting, haddock/pollock/saithe (Melanogrammus aeglefinus/Pollachius pollachius/P. virens) and hake Merluccius merluccius all exhibited significant amplification in length with the application of DC, increasing by 48,54 , and $72 \%$, respectively. While herring Clupea harengus, ling Molva molva and lemon sole Microstomus kitt displayed the most notable increases in length, their contribution to the overall diet consisted of 1 or 2 individuals, suggesting that the application of DC may not be suitable for sample sizes under a certain number. Prey biomass increased with the application of DC in most cases, however wrasse (Labridae), mackerel Scomber scombrus, dover sole Solea solea, and squid all displayed a decrease in biomass. To account for complete digestion of hard parts, NCF were applied to reconstructed prey biomass (Table 3). The species for which no NCF exist $(\mathrm{n}=363)$ were excluded from this analysis and their uncorrected values are not included in Table 3. The weight of all remaining prey species increased noticeably, with the mean weight of fish increasing from $92.7( \pm 200.0 \mathrm{SE})$ to $139.0 \mathrm{~g}( \pm 292.7 \mathrm{SE})$. Salmonids, sandeels, and dragonets exhibited the largest differences with weight increasing by 61,186 , and $227 \%$, respectively. When total biomass was calculated from corrected weight, the relative proportions of salmonids, sandeels, dragonets, and herring increased whilst other prey species exhibited reductions in biomass ranging between 0.1 and $7 \%$ (Table 3). Overall, Gadiformes, squid and salmonids contributed the largest proportion of biomass to the diet $(21,24$ and $36 \%$ corrected biomass, respectively). The majority of commercially important fish species such as haddock/pollock/saithe, whiting, ling and hake represented only a small percentage of the diet in terms of biomass. Despite occurring in high abundance, dragonets, sandeels and Trisopterus species contributed little in terms of biomass. When no NCF were applied, salmonid biomass contribution was $31 \%$, while gadoids contributed $27 \%$. Conversely, when NCF were applied, salmonid contribution rose to $36 \%$ while gadoid biomass dropped to $21 \%$. However, it should be noted that the biomass contribution of other prey species may be significantly underestimated due to the lack of DC and NCF for other diagnostic structures apart from otoliths. Table S3 in the Supplement displays the overall diet composition of grey seals for both years amalgamated. The percentage biomass column includes the uncorrected biomass for those species for which no correction factors were available, with the NCF corrected biomass. 
Table 1. Diet composition of grey seals Halichoerus grypus off southwest Ireland. All biomass values are re-created from uncorrected weights using an 'all structures' approach. \%F: percentage frequency of occurrence; \%N: percentage by number; $\%$ B: percentage by biomass

\begin{tabular}{|c|c|c|c|c|c|c|}
\hline \multirow[t]{2}{*}{ Species } & \multicolumn{3}{|c|}{$-2009 \longleftarrow$} & \multirow[b]{2}{*}{$\% \mathrm{~F}$} & \multirow{2}{*}{$\begin{array}{l}2010 \\
\% \mathrm{~N}\end{array}$} & \multirow[b]{2}{*}{$\% \mathrm{~B}$} \\
\hline & $\% \mathrm{~F}$ & $\% \mathrm{~N}$ & $\% \mathrm{~B}$ & & & \\
\hline \multicolumn{7}{|l|}{ AGNATHANS } \\
\hline $\begin{array}{l}\text { Petromyzon marinus (lamprey) } \\
\text { CHONDRICHTHYES }\end{array}$ & 2.4 & $<0.1$ & 4.8 & 2.0 & 0.2 & 2.4 \\
\hline \multicolumn{7}{|l|}{ TELEOSTI } \\
\hline \multicolumn{7}{|l|}{ Anguilliformes } \\
\hline Unidentified Anguilliformes (eels) & - & - & - & 2.0 & 0.2 & $<0.01$ \\
\hline Conger conger (conger eel) & 1.2 & 0.2 & $<0.1$ & - & - & - \\
\hline \multicolumn{7}{|l|}{ Clupiformes } \\
\hline Clupea harengus (herring) & 2.4 & 0.4 & 0.3 & - & - & - \\
\hline \multicolumn{7}{|l|}{ Salmoniformes } \\
\hline $\begin{array}{l}\text { Salmonidae } \\
\text { Gadiformes }\end{array}$ & \multicolumn{5}{|c|}{ Gadiformes } & 16.5 \\
\hline Melanogrammus aeglefinus (haddock) & 1.2 & 0.2 & 0.2 & 2.0 & 0.2 & 0.3 \\
\hline Pollachius pollachius/Pollachius virens (pollock/saithe) & 7.2 & 1.9 & 4.2 & 16.3 & 2.3 & 5.4 \\
\hline Merlangius merlangus (whiting) & 14.5 & 4.1 & 2.7 & 16.3 & 1.9 & 1.2 \\
\hline Micromesistius poutassou (blue whiting) & 8.4 & 2.1 & 0.8 & 24.5 & 4.0 & 1.1 \\
\hline Trisopterus esmarkii (Norway pout) & 3.6 & 0.6 & 0.1 & - & - & - \\
\hline Trisopterus minutus (poor cod) & 22.9 & 5.1 & 3.0 & 14.3 & 2.1 & 0.7 \\
\hline Trisopterus luscus (bib) & 13.3 & 3.2 & 2.6 & 16.3 & 2.3 & 1.8 \\
\hline Trisopterus minutus/luscus (poor cod/bib) & 16.9 & 9.9 & 4.4 & 16.3 & 2.8 & 1.0 \\
\hline Unidentified Trisopterus spp. & 26.5 & 8.6 & 1.6 & 40.8 & 7.4 & 1.5 \\
\hline Total Trisopterus spp. & 50.6 & 27.4 & 11.6 & 53.1 & 14.6 & $\underline{5.0}$ \\
\hline Ciliata mustela (5-beareded rockling) & $\overline{1.2}$ & $\overline{0.2}$ & $\overline{0.5}$ & $\overline{-}$ & $\overline{-}$ & $\overline{-}$ \\
\hline Gaidropsarus vulgaris (3-bearded rockling) & 1.2 & 0.4 & 3.3 & 2.0 & 0.2 & 2.6 \\
\hline Molva molva (ling) & - & - & - & 2.0 & 0.2 & 1.0 \\
\hline Unidentified Gadidae & 30.1 & 7.7 & 5.3 & 38.8 & 5.7 & 3.5 \\
\hline Merluccius merluccius (hake) & 1.2 & 0.2 & 0.1 & 8.2 & 0.8 & 1.2 \\
\hline Total Gadiformes & $\underline{79.5}$ & $\underline{44.3}$ & $\underline{28.8}$ & $\underline{79.6}$ & $\underline{30.1}$ & $\underline{21.3}$ \\
\hline \multicolumn{7}{|l|}{$\overline{\text { Scorpaeniformes }}$} \\
\hline Triglidae & 2.4 & 0.4 & 1.9 & - & - & - \\
\hline \multicolumn{7}{|l|}{ Perciformes } \\
\hline Perca fluviatilis (perch) & 1.2 & 0.2 & $<0.1$ & - & - & - \\
\hline Trachurus trachurus (scad) & 1.2 & 0.2 & 0.3 & 4.1 & 0.4 & 0.6 \\
\hline Labrus mixtus (cuckoo wrasse) & 1.2 & 0.2 & 0.4 & 2.0 & 0.2 & 0.2 \\
\hline Labrus bergylta (ballan wrasse) & 1.2 & 0.2 & 0.3 & 2.0 & 0.2 & 0.2 \\
\hline Unidentified Labridae (wrasse) & 8.4 & 3.2 & 2.8 & - & - & - \\
\hline Zoarces viviparus (eelpout) ${ }^{\mathrm{a}}$ & 4.8 & 2.1 & 4.9 & - & - & - \\
\hline Ammodytidae (sandeels) & 21.7 & 11.6 & 2.8 & 65.3 & 50.4 & 5.6 \\
\hline Callionymus spp. (dragonets) & 36.1 & 10.3 & 2.9 & 24.5 & 2.8 & 0.9 \\
\hline Caragobius urolepis (scaleless worm goby) & 3.6 & 0.6 & 0.1 & - & - & - \\
\hline Scomber scombrus (mackerel) & - & - & - & 2.0 & 0.2 & 3.6 \\
\hline \multicolumn{7}{|l|}{ Pleuronectiformes } \\
\hline Arnoglossus laterna (scaldfish) & 1.2 & 0.2 & 0.2 & - & - & - \\
\hline Platichthys flesus (European flounder) & 1.2 & 0.2 & 3.6 & - & - & - \\
\hline Limanda limanda $(\mathrm{dab})^{\mathrm{a}}$ & 1.2 & 0.2 & 1.0 & 2.0 & 0.2 & 1.0 \\
\hline Hippoglossus platessoides (long rough dab) & 2.4 & 0.4 & 0.4 & - & - & - \\
\hline Microstomus kitt (lemon sole) & 4.8 & 1.1 & 1.8 & 8.2 & 0.8 & 1.9 \\
\hline Glyptocephalus cynoglossus (witch) & - & - & - & 4.1 & 0.4 & 0.1 \\
\hline Hippoglossus hippoglossus (halibut) & 2.4 & 0.9 & 2.3 & - & - & - \\
\hline Solea solea (Dover sole) & 2.4 & 0.6 & 2.7 & 2.0 & 0.2 & 0.9 \\
\hline Buglossidium luteum (solenette) & 1.2 & 0.2 & 0.1 & 4.1 & 0.4 & 0.2 \\
\hline Unidentified flatfish & 7.2 & 1.5 & 2.5 & 14.3 & 1.5 & 3.7 \\
\hline Total Pleuronectiformes & 21.7 & 5.4 & 14.5 & 30.6 & 3.6 & 7.7 \\
\hline$\overline{\text { Unidentified fish species }}$ & $\overline{49.4}$ & $\overline{12.6}$ & - & $\overline{30.6}$ & $\overline{6.6}$ & - \\
\hline \multicolumn{7}{|l|}{ CEPHALOPODA } \\
\hline Loligo spp. (squid) & 3.6 & 0.6 & 4.1 & 4.1 & 0.6 & 40.8 \\
\hline Octopus spp. & 4.8 & 0.9 & 2.8 & 2.0 & 0.2 & $<0.01$ \\
\hline Total Cephalopoda & 8.4 & 1.5 & 6.9 & 6.1 & 0.8 & 40.8 \\
\hline
\end{tabular}


Table 2. Reconstructed prey lengths and percentage biomass with and without the application of digestion coefficients. \% B: percentage by biomass

\begin{tabular}{|c|c|c|c|c|c|c|c|}
\hline \multirow[t]{2}{*}{ Species } & \multirow[t]{2}{*}{$\mathrm{N}$} & \multicolumn{3}{|c|}{ — Uncorrected length $(\mathrm{cm})-$} & \multicolumn{3}{|c|}{ Corrected length $(\mathrm{cm})$} \\
\hline & & Range & Mean $\pm \mathrm{SD}$ & $\% \mathrm{~B}$ & Range & Mean \pm SD & $\% \mathrm{~B}$ \\
\hline \multicolumn{8}{|l|}{ Anguilliformes } \\
\hline Conger eel & 1 & - & 6.9 & $<0.1$ & - & 8.6 & $<0.1$ \\
\hline Unidentified eels & 1 & - & 1.7 & $<0.01$ & - & 2.1 & $<0.01$ \\
\hline \multicolumn{8}{|l|}{ Clupiformes } \\
\hline Herring & 2 & $16.5-25.2$ & $20.9 \pm 6.2$ & 0.3 & $26.6-86.3$ & $56.4 \pm 42.2$ & 0.6 \\
\hline \multicolumn{8}{|l|}{ Gadiformes } \\
\hline Haddock/pollock/saithe & 19 & $14.1-38.8$ & $28.4 \pm 6.1$ & 8.1 & $31.2-58.0$ & $43.7 \pm 8.6$ & 11.4 \\
\hline Whiting & 20 & $14.7-25.1$ & $20.0 \pm 2.7$ & 2.8 & $22.2-36.2$ & $29.4 \pm 4.3$ & 2.8 \\
\hline Blue whiting & 27 & $8.9-27.4$ & $17.6 \pm 4.0$ & 1.6 & $15.8-33.3$ & $23.5 \pm 4.1$ & 2.9 \\
\hline Trisopterus spp. & 150 & $3.1-28.1$ & $15.1 \pm 5.0$ & 13.0 & $3.9-36.3$ & $19.6 \pm 6.6$ & 13.1 \\
\hline Rocklings (3 \& 5-bearded) & 4 & $38.2-66.4$ & $53.3 \pm 15.2$ & 6.8 & $62.9-106.2$ & $86.0 \pm 23.5$ & 18.0 \\
\hline Ling & 1 & - & 49.1 & 1.0 & - & 97.6 & 3.3 \\
\hline Unidentified Gadidae spp. & 20 & $7.2-21.2$ & $15.2 \pm 3.8$ & 2.7 & $14.4-36.0$ & $26.2 \pm 5.9$ & 5.3 \\
\hline Hake & 5 & $20.3-31.0$ & $26.4 \pm 4.6$ & 1.2 & $33.8-54.7$ & $45.5 \pm 9.1$ & 2.5 \\
\hline \multicolumn{8}{|l|}{ Perciformes } \\
\hline Perch & 1 & - & 13.1 & $<0.1$ & - & 17.3 & $<0.1$ \\
\hline Scad & 1 & - & 26.4 & 0.3 & - & 33.6 & 0.3 \\
\hline $\begin{array}{l}\text { Wrasse (cuckoo, ballan, } \\
\text { unidentified) }\end{array}$ & 15 & $16.8-27.2$ & $21.3 \pm 2.7$ & 3.1 & $21.1-34.2$ & $26.7 \pm 3.4$ & 2.7 \\
\hline Sandeels & 249 & $8.3-55.2$ & $15.2 \pm 60.0$ & 7.0 & $12.0-85.0$ & $22.6 \pm 9.3$ & 8.1 \\
\hline Dragonets & 14 & $12.7-26.4$ & $19.4 \pm 40.0$ & 1.5 & $24.4-50.8$ & $36.9 \pm 7.6$ & 4.3 \\
\hline Scaleless worm goby & 3 & $6.9-9.9$ & $9.0 \pm 1.9$ & $<0.1$ & $12.4-20.0$ & $16.7 \pm 3.9$ & 0.2 \\
\hline Mackerel & 1 & - & 59.9 & 3.5 & - & 73.9 & 2.7 \\
\hline \multicolumn{8}{|l|}{ Pleuronectiformes } \\
\hline Long rough dab & 2 & $22.2-24.6$ & $23.4 \pm 1.7$ & 0.4 & $30.7-33.8$ & $32.2 \pm 2.3$ & 0.4 \\
\hline Lemon sole & 1 & - & 17.0 & 0.1 & - & 41.9 & 0.7 \\
\hline Witch & 1 & - & 15.1 & $<0.1$ & - & 19.1 & $<0.1$ \\
\hline Dover sole & 4 & $31.1-38.8$ & $35.1 \pm 3.1$ & 3.4 & $39.2-48.8$ & $44.2 \pm 3.9$ & 2.8 \\
\hline Solenette & 1 & - & 17.2 & 0.1 & - & 21.5 & 0.1 \\
\hline Unidentified flatfish species & 3 & $9.5-23.8$ & $15.3 \pm 7.5$ & 0.3 & $12.5-30.4$ & $19.7 \pm 9.4$ & 0.3 \\
\hline Squid & 6 & $21.1-80.1$ & $48.9 \pm 24.0$ & 42.8 & $21.6-81.7$ & $50.0 \pm 24.5$ & 17.6 \\
\hline
\end{tabular}

\section{Feeding strategy}

A modified version of the Costello feeding plot (Amundsen et al. 1996) was produced for all prey species identified within scat samples. When taking prey-specific abundance into account, the majority of prey types were unimportant, and eaten only occasionally by some predators (Fig. 3a). Trisopterus spp. were eaten by more than half of the seals, while sandeels appear on the edge of becoming a specialised prey taxa.

In terms of prey-specific biomass, again many prey types were unimportant to the diet and taken in small quantities, thus their contribution to the diet in terms of biomass was minor (Fig. 3b). However, a high between-phenotype contribution to the niche width was observed, with individual seals specialising on a variety of prey types, although each prey group was consumed by only a narrow fraction of the seal population. While Trisopterus spp. and sandeels may have been important in terms of their abundance, their contribution to the diet in terms of biomass was minimal. Although salmonid occurrence was relatively low, their biomass contribution to the diet was important, though again it appears that only a few seals specialise on this taxa.

\section{Inter-annual variation}

MDS plots of square-root transformed abundance data highlighted 2 samples as outliers. One of these samples was shown to contain only a single hake, while another contained 7 pelagic gadoid species. An MDS was run on a subset of the data excluding both these samples, showing a general overlap between samples based on sampling year. A PERMANOVA+ highlighted a significant effect of year $(\mathrm{p}=0.002$, pseudo- $F=4.47, \mathrm{df}=1$ ). The SIMPER routine was run to highlight the species responsible for the greatest 
Table 3. Reconstructed prey weights with and without the application of numerical correction factors (NCF). \%B: percentage by biomass

\begin{tabular}{|c|c|c|c|c|c|c|c|}
\hline \multirow[t]{2}{*}{ Species } & \multirow[t]{2}{*}{$\mathrm{N}$} & \multicolumn{3}{|c|}{ Without NCF - } & \multirow[b]{2}{*}{ Weight (g) } & \multirow{2}{*}{$\begin{array}{l}\text { With NCF } \\
\quad \text { Mean } \pm \text { SD }\end{array}$} & \multirow[b]{2}{*}{$\% \mathrm{~B}$} \\
\hline & & Weight (g) & Mean \pm SD & $\% \mathrm{~B}$ & & & \\
\hline \multicolumn{8}{|l|}{ Clupiformes } \\
\hline Herring & 2 & 142.2 & $71.1 \pm 65.2$ & 0.2 & 407.7 & $203.9 \pm 186.8$ & 0.4 \\
\hline \multicolumn{8}{|l|}{ Salmoniformes } \\
\hline Salmon/trout & 46 & 23388.4 & $508.4 \pm 283.3$ & 30.7 & 37655.4 & $818.6 \pm 456.2$ & 36.2 \\
\hline \multicolumn{8}{|l|}{ Gadiformes } \\
\hline Haddock/pollock/saithe & 19 & 4430.0 & $233.2 \pm 137.8$ & 5.8 & 4930.9 & $259.5 \pm 153.3$ & 4.7 \\
\hline Whiting & 20 & 1542.7 & $77.1 \pm 30.5$ & 2.0 & 1584.4 & $79.2 \pm 31.3$ & 1.5 \\
\hline Blue whiting & 27 & 898.9 & $33.3 \pm 24.3$ & 1.2 & 923.2 & $34.2 \pm 24.9$ & 0.9 \\
\hline Trisopterus species & 150 & 7113.2 & $47.4 \pm 53.5$ & 9.3 & 7648.8 & $51.0 \pm 57.2$ & 7.3 \\
\hline Rocklings (3 \& 5-bearded) & 4 & 3722.7 & $930.7 \pm 551.4$ & 4.9 & 3979.5 & $994.9 \pm 589.0$ & 3.8 \\
\hline Ling & 1 & - & 547.2 & 0.7 & - & 584.9 & 0.6 \\
\hline Unidentified Gadidae species & 20 & 1462.7 & $73.1 \pm 49.1$ & 1.9 & 1563.7 & $78.2 \pm 52.5$ & 1.5 \\
\hline Hake & 5 & 685.0 & $137.0 \pm 74.3$ & 0.9 & 740.5 & $148.1 \pm 80.3$ & 0.7 \\
\hline \multicolumn{8}{|l|}{ Perciformes } \\
\hline Sandeels & 249 & 3848.1 & $15.5 \pm 25.9$ & 5.0 & 11009.3 & $44.2 \pm 74.2$ & 10.6 \\
\hline Dragonets & 14 & 802.2 & $57.3 \pm 34.4$ & 1.1 & 2625.6 & $187.5 \pm 112.7$ & 2.5 \\
\hline Mackerel & 1 & - & 1906.5 & 2.5 & - & 2652.0 & 2.5 \\
\hline \multicolumn{8}{|l|}{ Pleuronectiformes } \\
\hline Long rough dab & 2 & 193.1 & $96.6 \pm 23.7$ & 0.3 & 224.6 & $112.3 \pm 27.5$ & 0.2 \\
\hline Lemon sole & 1 & - & 54.3 & 0.1 & - & 83.6 & 0.1 \\
\hline Witch & 1 & - & 16.8 & $<0.1$ & - & 17.4 & $<0.1$ \\
\hline Dover sole & 4 & 1845.5 & $461.4 \pm 132.3$ & 2.4 & 2290.3 & $572.6 \pm 164.2$ & 2.2 \\
\hline Solenette & 1 & - & 52.6 & 0.1 & - & 65.2 & 0.1 \\
\hline Unidentified flatfish species & 3 & 179.8 & $59.9 \pm 77.6$ & 0.2 & 223.1 & $74.4 \pm 96.2$ & 0.2 \\
\hline Squid & 6 & 23447.4 & $3907.9 \pm 4080.6$ & 30.7 & 24901.1 & $4150.2 \pm 4333.6$ & 23.9 \\
\hline
\end{tabular}

difference in diet between sampling years (Table 4). Sandeels were far more important in the seals' diet in 2010 than in 2009 (Table 1), accounting for $19 \%$ of the dissimilarity displayed between years. Trisopterus spp. were important contributors to grey seal diet in both years, however, their higher abundance in 2009 accounted for $15 \%$ of the dissimilarity between years.
MDS plots and PERMANOVA+ statistical tests were also conducted on uncorrected and corrected (where NCF values were available) biomass data. The PERMANOVA+ highlighted a significant effect of year for both uncorrected biomass ( $p=0.045$, pseudo- $F=1.96, \mathrm{df}=1)$ and corrected biomass ( $\mathrm{p}=$ 0.029 , pseudo- $F=2.09$, df $=1$ ). The SIMPER routine
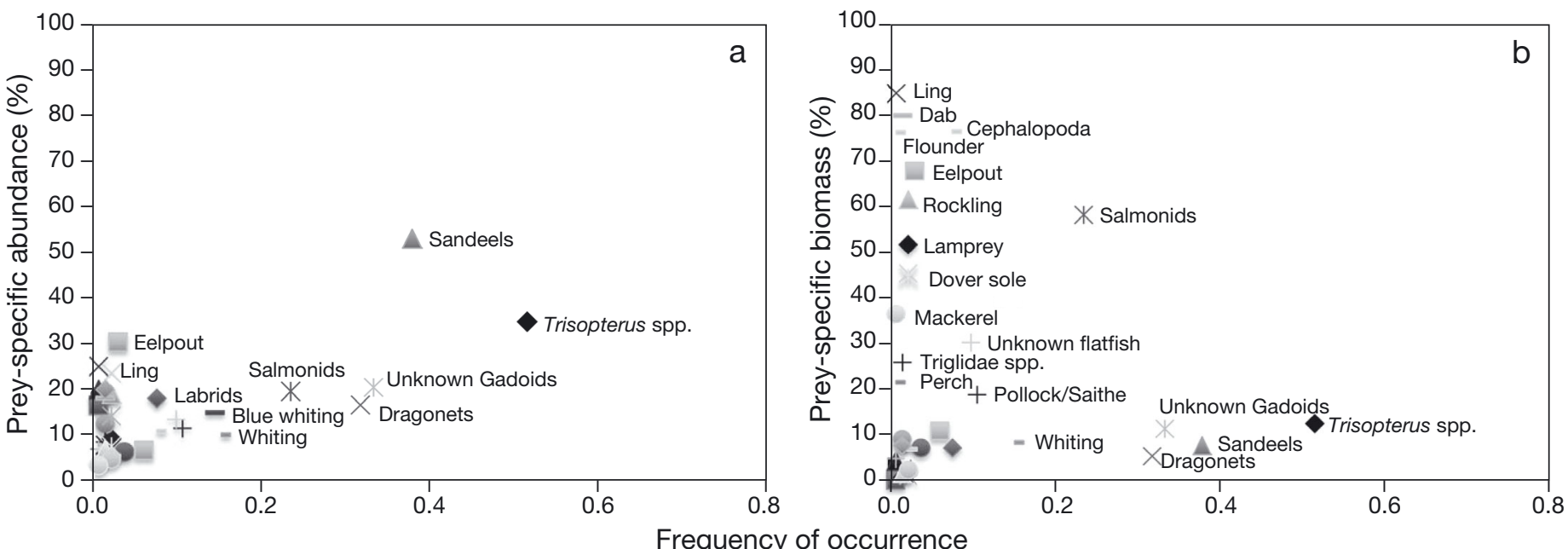

Frequency of occurrence

Fig. 3. Halichoerus grypus. Feeding strategy plot (following Amundsen et al. 1996) displaying main prey species within the grey seal diet in southwest Ireland. (a) Prey-specific abundance, (b) prey-specific uncorrected biomass 
Table 4. Species accounting for the greatest difference between samples collected in 2009 and 2010 expressed as abundance, uncorrected biomass, and corrected biomass. Contribution \% indicates the \% contribution to Bray-Curtis dissimilarity. \%B: percentage by biomass

\begin{tabular}{|c|c|c|c|}
\hline \multirow{2}{*}{ Species } & \multicolumn{3}{|c|}{ - Contribution \% } \\
\hline & $\begin{array}{l}\text { Abun- } \\
\text { dance }\end{array}$ & $\begin{array}{c}\text { Uncorrected } \\
\% B\end{array}$ & $\begin{array}{c}\text { Corrected } \\
\% \mathrm{~B}\end{array}$ \\
\hline Blue whiting & 4.66 & - & - \\
\hline Cephalopds & 4.70 & 8.06 & 7.73 \\
\hline Dragonets & 7.69 & - & 3.35 \\
\hline Flatfish & 6.51 & 3.16 & 2.90 \\
\hline Haddock/pollack/saithe & 3.59 & 6.42 & 5.65 \\
\hline Rocklings & - & 5.74 & 5.24 \\
\hline Salmonids & 6.90 & 28.71 & 30.46 \\
\hline Sandeels & 19.04 & 12.63 & 17.42 \\
\hline Trisopterus spp. & 15.20 & 11.45 & 8.85 \\
\hline Unidentified fish & 10.36 & - & - \\
\hline Unidentified gadoids & 9.71 & 3.09 & - \\
\hline Whiting & 4.42 & - & - \\
\hline
\end{tabular}

was again run to highlight the species responsible for the greatest difference in diet between sampling years (Table 4); this time, salmonids were the highest contributors to the dissimilarities between years, followed by sandeels and then Trisopterus spp. The same pattern is true for both uncorrected and corrected biomass values.

\section{DISCUSSION}

Traditionally, analysis of marine mammal diet has relied on visual identification of particular hard part remains of prey, such as fish otoliths and cephalopod beaks within faeces and stomach contents, as these are largely resistant to the processes of digestion (Pierce et al. 1990, 1991). However, when using this method there are a number of issues which may lead to certain components of the diet being underestimated or excluded (Olesiuk et al. 1990, Tollit et al. 1997, Bowen 2000, Grellier \& Hammond 2006, Tollit et al. 2007). We therefore used all hard part structures in this study to minimise bias and increase the likelihood of identifying other prey species, as reported in other studies (e.g. Fernandez et al. 2009, Hernandez-Milian \& Rogan 2011). In doing so, we found that dragonet abundance increased by $333.57 \%$ when other hard structures in addition to otoliths were used for identification. Additionally, a further 11 species (37\% of all prey items) were identified through other skeletal structures alone, including salmonids. While grey seal predation on north
Atlantic salmonids has been documented (Lenky \& Sjare 2011), there is little evidence from dietary studies to support these observations. For example, studies in the northeast of Scotland have found very little evidence of salmonids in the diet (McConnell et al. 1984, Prime \& Hammond 1985). Kavanagh et al. (2010) reported salmonids occurring in $3 \%$ of scat samples collected from harbour seal Phoca vitulina vitulina haul-out sites on the west coast of Ireland, but until now, no studies have found evidence of salmonids in the diet of grey seals in Ireland. Using bony material in addition to otoliths, this study has demonstrated that grey seals in southwest Ireland are consuming salmonids. These results thus support the principle that an 'all structures' approach to pinniped diet estimation can significantly increase the rate of detection for most fish groups, and result in improved estimation of seal diet. Nevertheless, like most methods, caution is still required when using the 'all structures' approach. Species with bones more robust to digestion may be overestimated (e.g. dragonets) compared to other species with softer, more digestible bones (e.g. clupeoids). Therefore, while the 'all structures' method can significantly improve the probability of prey detection, it may bias results when calculating each species' contribution to the diet. Furthermore, the lack of published regression equations for many species may lead to their biomass being under/overestimated within the diet when using either average length/mass values from FishBase (i.e. for dab Limanda limanda and sea lamprey in this study), or websites such as www. letsflyfish.com when calculating salmon weight.

The use of correction factors is also important when reconstructing prey length/biomass. This study demonstrated an overall increase of $46 \%$ in teleost fish length when digestion coefficients were applied. However, species-specific numerical correction factors have yet to be derived for otoliths of many species and therefore coarse/average correction factors have to be relied on, introducing potential biases. Intra-specific variation in otolith digestion, and a lack of correction factors for diagnostic structures other than otoliths (e.g. salmonid premaxillae) introduces further bias. Nonetheless, the use of numerical correction factors increased our estimate of total biomass of sandeels in the grey seal diet by $186 \%$, whilst only increasing their relative contribution to diet in terms of biomass by $6 \%$. Given the small size of sandeels, such a minute change in biomass contribution to the diet is to be expected. The average weight of salmonids (one of the largest prey identified within this study) was over 18 times greater than the 
average weight of sandeels. However, when numerical correction factors were applied, salmonid biomass contribution to the diet increased by only $6 \%$. It should also be noted that applying numerical correction factors only to those species for which there are published data will disproportionately overestimate their importance, while underestimating the contribution of species for which correction factors are not available, or those species identified solely from bones (e.g. rays, lampreys). Therefore, while this study provides a good indication of which species are the most important contributors to the seals diet in terms of biomass, it is not a true reflection of the overall diet of grey seals in this region.

This study has revealed that grey seals using the Great Blasket Island in southwest Ireland are generalist feeders, consistent with studies in other parts of the species' range (Bowen et al. 2006, Beck et al. 2007, Ridoux et al. 2007). Previous dietary studies conducted in Ireland in the 1990s indicated that grey seals displayed a wide range of prey preferences, feeding predominantly on demersal species, sandeels, ling and cephalopods (Cronin et al. 2010 and references therein). These studies also showed that with the exception of whiting, plaice Pleuronectes platessa and sole, commercial fish species do not feature prominently in the diet of grey seals. Our study found that while grey seals consume a wide range of prey species, only a small number occurred in high frequencies within the diet (e.g. Trisopterus spp. and sandeels). Although Trisopterus spp., unidentified fish, sandeels, unidentified gadoids, dragonets, and salmonids all displayed greater frequencies of occurrence compared with all other prey types, no one species dominated the diet. This confirms the view that while it is likely grey seals may be specialist predators at an individual scale, they are generalist predators at a population scale. Teleost fish dominated the seals' diet numerically while Gadiformes were the most important prey order. The importance of gadoids and sandeels to the overall diet is in agreement with previous dietary studies carried out in the northwest Atlantic (Bowen \& Harrison 1994) and the North Sea (Prime \& Hammond 1990). This is, however, the first study within the northeast Atlantic to identify Trisopterus spp. in such high numbers in grey seal diet. The study site is used by a mixed colony of grey seals with adults and juveniles of both genders present, and distributed in a mixed group across the site. Whilst we cannot determine what age/gender components of the colony contributed to the diet data, scat was collected randomly across the site and likely represents the diet of the mixed haul-out group.
The majority of commercially important species consumed by grey seals in this study were taken in relatively low quantities (with the exception of salmonids, blue whiting and whiting). Furthermore, seals sought out smaller fish, with $97 \%$ of prey items less than $50 \mathrm{~cm}$ in corrected length - again suggesting a lack of direct competition with commercial fisheries. However, the removal of small or juvenile fish may impact on commercial fisheries indirectly through lower recruitment to fish stocks. The majority of species consumed by grey seals off the southwest coast, however, are not targeted by the fishing industry. Grey seal diet in this region appears to consist mainly of demersal, inshore species. This is in agreement with previous telemetry studies which demonstrated a largely inshore distribution of grey seal foraging effort, with most foraging trips occurring within $50 \mathrm{~km}$ of the study site (Cronin et al. 2013), and $70 \%$ of seal dives directed to the benthos (Jessopp et al. 2013).

Salmonids and squid were the most important contributors in terms of biomass to grey seal diet in southwest Ireland. Although sandeels were important numerically, their contribution to the diet in terms of biomass was low. Salmonids contributed $36 \%$ in terms of corrected biomass to the diet of grey seals in this study, indicating that salmonids form an important component of the seals' diet in this region during these periods. Salmonid remains were recovered from $25 \%$ of samples, yet the actual number of salmonids taken by seals may have been greater. Seals are known to take bites from the soft belly of large fish, often not consuming the head (which contains the otoliths), leading to salmon and other species frequently being underestimated in seal diet (Butler et al. 2006).

Seal interactions with salmon fisheries can include predation on salmon stocks entering rivers, interference and mortality of salmon in inshore commercial fisheries and at aquaculture sites, and predation of outward migrating salmon smolts. Whilst the driftnet salmon fishery is no longer operational in Ireland, it is acknowledged that seals interact with salmon fisheries in many Irish salmon rivers/estuaries and depredate salmon in fish farms in Ireland (Cronin et al. 2010), with seals considered as problem predators at $81 \%$ of marine salmon farms in Scotland (Quick et al. 2004). It is possible that salmonids found in the diet of seals in this study originated in salmon fish farms in the vicinity $(<80 \mathrm{~km})$ of the study area (e.g. Bantry Bay Co. Cork, and Deenish Island Co. Kerry). Unfortunately, robust data on predation levels by seals at salmon farms in Ireland does not exist, so it is 
not possible to examine any potential inter-annual variation in seal attacks on salmon farms to explain the inter-annual variation in diet evident in this study. Alternatively, the availability of sea trout within coastal waters at this time of year could explain the high presence of salmonids within the seal's diet (e.g. the Caragh River in Co. Kerry, approximately $40 \mathrm{~km}$ northeast of the Blasket Islands, experiences a good run of sea trout in early spring).

It is also likely that the salmonids found in the diet of grey seals in southwest Ireland comprise both salmon and sea trout, although conclusive identification of species remains elusive. This is because all salmonids in this study were identified from a fragment of bone, which makes distinguishing between the 2 species impossible. Due to the sensitive nature of issues regarding seal-salmonid interactions, the conclusive identification of different salmonids within the grey seals diet is imperative. Genetic techniques have previously been used to identify salmon in the diet of seals (Parsons et al. 2005), and recent advancements in demonstrating genetic differences between wild and farmed salmon (e.g. Karlsson et al. 2011) could be applied in the future. Given the high abundance of skeletal remains recovered from scat samples, extraction of mitochondrial DNA from bones is a useful technique in distinguishing between salmon and sea trout species (Purcell et al. 2004). Furthermore, Matejusová et al. (2008) successfully demonstrated the potential of using quantitative PCR techniques in differentiating and quantifying salmonid species from within pinniped scat samples. Such species-specific identification would be an obvious way forward in establishing whether or not seal populations are consuming salmon (and whether this salmon is wild or farmed) or sea trout. This information is vital for addressing concerns regarding seal predation pressure on Irish salmonid stocks. Atlantic salmon stocks have declined by $75 \%$ in recent years (Anon 2008), and although conservation measures have been put in place, salmon stocks in many Irish rivers are below their conservation limits. With declines in fish stocks there has been increased interest in the extent of competition for resources between commercial fisheries and seals.

Yearly differences in species composition were observed within the diet. Sandeel abundance was over 4 times higher during 2010, while blue whiting numbers were approximately 3 times higher in 2010. Salmonid abundance was slightly higher in 2009. These variations are also reflected in each prey group's relative biomass contribution to the diet. It is probable that these yearly differences can be attri- buted to variations in either spawning/migration times or recruitment levels of prey. For example, blue whiting recruitment was over 3 times higher in 2010 compared to 2009 (Stock Book 2012), indicating that seal diet is reflecting abundance. Interestingly, higher occurrences of unidentified fish and dragonets were noted in the diet during 2009 compared to 2010, when sandeels and blue whiting were less abundant, highlighting a possible ability of grey seals to switch to alternative food sources when previously abundant species begin to decline (Pierce et al. 1991). While the sample sizes from both years are relatively small (83 scats for 2009 and 53 for 2010), this was still a sufficient number to identify significant differences in diet between years. However, caution should be taken when inferring any temporal differences in diet composition from smaller sample sizes, as this may be a result of sampling bias.

\section{CONCLUSION}

The variations in diet composition exhibited by grey seals off the southwest coast of Ireland supports the theory that as generalists, grey seals likely forage on locally and seasonally abundant prey species. However, in order to acquire a more accurate representation of the overall diet composition of grey seals in the area, long term year-round sampling is necessary, as the present study was limited to 2 years and focused only on the spring period. Furthermore, investigations into the diet composition of grey seals that occur in other areas around the coast of Ireland would allow regional differences in diet and foraging strategies to be explored, and would put the findings in southwest Ireland into a national and European context. We identified the presence of salmonids in the diet of grey seals for the first time in Ireland, and established that they constitute an important part of the diet of grey seals during the spring period in southwest Ireland. We suggest that an 'all structures' approach to pinniped diet estimation can significantly increase the rate of detection for most fish groups, and result in improved estimation of seal diet. Further efforts are required to definitively identify whether seals are consuming wild Atlantic salmon, sea trout, or a combination of the 2 . This information is critical for estimating salmonid biomass removal by seals, determining potential conflict with commercial fisheries, and for producing appropriate targeted conservation measures for Atlantic salmon-which remains below favourable conservation status in a number of Irish estuaries. 
Acknowledgements. Thank you to the National Parks and Wildlife Service staff and to S. Ratigan who assisted with scat collection. This analysis was funded under the Beaufort Ecosystem Approach to Fisheries Management Award, as part of the Irish Government's National Development Plan (NDP). The Beaufort Marine Research Award is grant aided by the Department of Communications, Energy and Natural Resources (DCENR) and the Department of Agriculture, Fisheries and Food (DAFF) under the Strategy for Science Technology and Innovation (SSTI) and the Sea Change Strategy.

\section{LITERATURE CITED}

Amundsen PA, Gabler HM, Staldvik FJ (1996) A new approach to graphical analysis of feeding strategy from stomach contents data-modification of the Costello (1990) method. J Fish Biol 48:607-614

Anderson MJ, Gorley RN, Clarke KR (2008) PERMANOVA+ for PRIMER: guide to software and statistical methods. PRIMER-E, Plymouth

Anon (2008) The status of EU protected habitats and species in Ireland. Conservation status in Ireland of habitats and species listed in the European Council Directive on the conservation of habitats, flora and fauna 92/43/EEC. National Parks and Wildlife Service, Department of Environment, Heritage and Local Government, Dublin

Austin D, Bowen WD, McMillan JI, Iverson SJ (2006) Linking movement, diving, and habitat to foraging success in a Large Marine Predator. Ecology 87:3095-3108

Bayhan B, Sever TM, Taskayak E (2008) Age, length-weight relationships and diet composition of scaldfish Arnoglossus laterna (Walbaum, 1792) (Pisces: Bothidae) in Izmir Bay (Aegean Sea). J Anim Vet Adv 7:924-929

> Beck CA, Iverson SJ, Bowen WD, Blanchard W (2007) Sex differences in grey seal diet reflect seasonal variation in foraging behaviour and reproductive expenditure: evidence from quantitative fatty acid signature analysis. J Anim Ecol 76:490-502

Bedford BC, Woolner LE, Jones BW (1986) Length-weight relationships for commercial fish species and conversion factors for various presentations. Fish Res Data Report No. 10, Minist Agric Fish Food, Lowestoft

Bowen WD (2000) Reconstruction of pinniped diets: accounting for complete digestion of otoliths and cephalopod beaks. Can J Fish Aquat Sci 57:898-905

Bowen WD, Harrison GD (1994) Offshore diet of grey seals Halichoerus grypus near Sable Island, Canada. Mar Ecol Prog Ser 112:1-11

Bowen WD, Beck CA, Iverson SJ, Austin D, McMillan JI (2006) Linking predator foraging behaviour and diet with variability in continental shelf ecosystems: grey seals of eastern Canada. In: Boyd IL, Wanless S, Camphuysen CJ (eds) Top predators in marine ecosystems: their role in monitoring and management. Cambridge University Press, Cambridge, p 63-81

> Breed GA, Bowen WD, McMillan JI, Leonard ML (2006) Sexual segregation of seasonal foraging habitats in a non-migratory marine mammal. Proc Biol Sci 273: 2319-2326

Brennan RE, Rodwell LD (2008) Sustainable management of wild Irish Atlantic salmon: keys found through the looking-glass. Mar Policy 32:1072-1079

Brown EG, Pierce GJ (1998) Monthly variation in the diet of harbour seals in inshore waters along the southeast Shetland (UK) coastline. Mar Ecol Prog Ser 167:275-289

- Butler JRA, Middlemas SJ, Graham IM, Thompson PM, Armstrong JD (2006) Modelling the impacts of removing seal predation from Atlantic salmon, Salmo salar, rivers in Scotland: a tool for targeting conflict resolution. Fish Manag Ecol 13:285-291

> Butler JRA, Middlemas SJ, McKelvey SA, McMyn I and others (2008) The Moray Firth Seal Management Plan: an adaptive framework for balancing the conservation of seals, salmon, fisheries and wildlife tourism in the UK. Aquat Conserv 18:1025-1038

- Butler JRA, Middlemass SJ, Graham IM, Harris RN (2011) Perceptions and costs of seal impacts on Atlantic salmon fisheries in the Moray Firth, Scotland: implications for the adaptive co-management of seal-fishery conflict. Mar Policy 35:317-323

- Byrne CJ, Poole R, Dillane M, Rogan G, Whelan KF (2004) Temporal and environmental influences on the variation in sea trout (Salmo trutta L.) smolt migration in the Burrishoole system in the west of Ireland from 1971 to 2000. Fish Res 66:85-94

> Carter TJ, Pierce GJ, Hislop JRG, Houseman JA, Boyle PR (2001) Predation by seals on salmonids in two Scottish estuaries. Fish Manag Ecol 8:207-225

Clarke MR (ed) (1986) A handbook for the identification of cephalopod beaks. Clarendon Press, Oxford

Clarke KR, Warwick RM (2001) Change in marine communities: an approach to statistical analysis and interpretation, $2^{\text {nd }}$ edn. PRIMER-E, Plymouth

Costello MJ (1990) Predator feeding strategy and prey importance: a new geographical analysis. J Fish Biol 36: 261-263

Cottrell PE, Trites AW, Miller EH (1996) Assessing the use of hard parts in faeces to identify harbour seal prey: results of captive-feeding trials. Can J Zool 74:875-880

Coull KA, Jermyn AS, Newton AW, Henderson GI, Hall WB (1989) Length/weight relationships for 88 species of fish encountered in the North East Atlantic. Scottish Fisheries Research Report No. 43, Department of Agriculture and Fisheries for Scotland, Aberdeen

Cronin M, Jessopp M, Reid D (2010) Seals and fish stocks in Irish waters. Study note to the European Parliament Directorate General for Internal Policies, Brussels

> Cronin M, Pomeroy P, Jessopp M (2013) Size and seasonal influences on the foraging range of female grey seals in the northeast Atlantic. Mar Biol 160:531-539

Fernandez R, Santos MB, Carrillo M, Tejedor M, Pierce GJ (2009) Stomach contents of cetaceans stranded in the Canary Islands 1996-2006. J Mar Biol Assoc UK 89: 873-883

Froese R, Pauly D (eds) (2013) FishBase. www.fishbase.org > Grellier K, Hammond PS (2005) Feeding method affects otolith digestion in captive gray seals: implications for diet composition estimation. Mar Mamm Sci 21:296-306

> Grellier K, Hammond PS (2006) Robust digestion and passage rate estimates for hard parts of grey seal (Halichoerus grypus) prey. Can J Fish Aquat Sci 63:1982-1998

Hammond PS, Hall AJ, Prime JH (1994) The diet of grey seals around Orkney and other island and mainland sites in north-eastern Scotland. J Appl Ecol 31:340-350

Härkönen T (1986) Guide to the otoliths of the bony fishes of the Northeast Atlantic. Danbui Aps, Hellerup

Hernandez-Milian G, Rogan E (2011) Unusual feeding of bottlenose dolphin (Tursiops truncatus Montagu, 1820) 
on dogfish (Scyliorhinus spp. L., 1758). Ir Nat J 31: 136-137

ICES (2003) Environmental status of the European seas. Federal Ministry for the Environment, Nature Conservation and Nuclear Safety, Berlin

lkyaz AT, Metin G, Soykan O, Kinacigil HT (2010) Age, growth and sexual development of solenette, Buglossidium luteum (Risso, 1810), in the central Aegean Sea. J Appl Ichthyol 26:436-440

Inland Fisheries Ireland (2012) Management of the wild salmon fishery. www.fisheriesireland.ie/Salmon-Regulations/ salmon-regulations.html

> Jessopp MJ, Cronin MA, Hart T (2013) Habitat-mediated dive behaviour in free-ranging grey seals. PLoS ONE 8:e63720

Karlsson S, Moen T, Lien S, Glover KA, Hindar K (2011) Generic genetic differences between farmed and wild Atlantic salmon identified from a 7K SNP-chip. Mol Ecol Resour 11:247-253

Kavanagh AS, Cronin MA, Walton M, Rogan E (2010) Diet of the harbour seal (Phoca vitulina vitulina) in the west and south-west of Ireland. J Mar Biol Assoc UK 90:1517-1527

Lenky CC, Sjare B (2011) Changes in seal habitat use of nearshore waters around Newfoundland and southern Labrador: implications for potential predation on salmon. Open Conserv Biol J 5:13-24

Leopold MF, van Damme CJG, Philippart CJM, Winter CJN (2001) Otoliths of North Sea fish: fish identification key by means of otoliths and other hard parts. World Biodiversity Database, Expert Centre for Taxonomic Identification, University of Amsterdam, Amsterdam

Matejusová I, Doig F, Middlemas S, MacKay S and others (2008) Using quantitative real-time PCR to detect salmonid prey in scats of grey Halichoerus grypus and harbour Phoca vitulina seals in Scotland: an experimental and field study. J Appl Ecol 45:632-640

McConnell BJ, Prime JH, Hiby AR, Harwood J (1984) Grey seal diet. In: Interactions between grey seals and UK fisheries. Sea Mammal Research Unit Scientific Report, Natural Environment Research Council, Cambridge, p 148-183

McConnell BJ, Fedak MA, Lovell P, Hammond PS (1999) Movements and foraging areas of grey seals in the North Sea. J Appl Ecol 36:573-590

Ó Cadhla O, Strong D (2007) Grey seal moult population survey in the Republic of Ireland, 2007. Report to the National Parks \& Wildlife Service, Department of the Environment, Heritage and Local Government, Dublin

Ó Cadhla O, Strong D, O'Keeffe C, Coleman M and others (2007) An assessment of the breeding population of grey seals in the Republic of Ireland, 2005. Irish Wildlife Manuals No. 34. National Parks \& Wildlife Service, Department of the Environment, Heritage and Local Government, Dublin

O'Sullivan S, Moriarty C, FitzGerald RD, Davenport J, Mulcahy MF (2003) Age, growth and reproductive status of the European conger eel, Conger conger (L.) in Irish coastal waters. Fish Res 64:55-69

Olesiuk PF, Bigg MA, Ellis GM, Crockford SJ, Wigen RJ (1990) An assessment of the feeding habits of harbour

Editorial responsibility: Christine Paetzold, Oldendorf/Luhe, Germany seals (Phoca vitulina) in the Strait of Georgia, British Columbia, based on scat analysis. Can Tech Rep Fish Aquat Sci No.1730

> Parsons KM, Piertney SB, Middlemas SJ, Hammond PS, Armstrong JD (2005) DNA-based identification of salmonid prey species in seal faeces. J Zool 266:275-281

> Pierce GJ, Boyle PR (1991) A review of methods for diet analysis in piscivorous marine mammals. Oceanogr Mar Biol Annu Rev 29:409-486

Pierce GJ, Boyle PR, Thompson PM (1990) Diet selection by seals. In: Barnes M, Gibson RN (eds) Trophic relationships in the marine environment. Proc $24^{\text {th }}$ Eur Mar Biol Symp, Oban, p 222-238

Pierce GJ, Boyle PR, Diack JSW (1991) Identification of fish otoliths and bones in faeces and digestive tracts of seals. J Zool 224:320-328

Pierce GJ, Boye PR, Watt J, Grisley M (1993) Recent advances in diet analysis of marine mammals. Symp Zool Soc Lond 66:241-261

Prime JH, Hammond PS (1985) The diet of grey seals in the North Sea assessed from faecal analysis. In: Hammond PS and Harwood J (eds) The impact of grey seals on North Sea resources. Sea Mammal Research Unit, Natural Environment Research Council, Cambridge, p 84-99

$>$ Prime JH, Hammond PS (1990) The diet of grey seals from the south-western North Sea assessed from analyses of hard parts found in faeces. J Appl Ecol 27:435-447

Purcell MK, Mackey G, LaHood E, Huber H, Park L (2004) Molecular methods for the genetic identification of salmonid prey from Pacific harbour seal (Phoca vitulina richardsi) scat. Fish Bull 102:213-220

Quick NJ, Middlemas SJ, Armstrong JD (2004) A survey of antipredator controls at marine salmon farms in Scotland. Aquaculture 230:169-180

Ridoux V, Spitz J, Vincent C, Walton MJ (2007) Grey seal diet at the southern limit of its European distribution: combining dietary analyses and fatty acid profiles. J Mar Biol Assoc UK 87:255-264

Santos MB, Fernández R, López A, Martínez JA, Pierce GJ (2007) Variability in the diet of bottlenose dolphin, Tursiops truncatus, in Galician waters, north-western Spain, 1990-2005. J Mar Biol Assoc UK 87:231-241

Stock Book (2012) Annual 2012 review of fish stocks with management advice for 2013. Fisheries Science Services Division, Marine Institute, Dublin

Tollit DJ, Steward PM, Thompson PM, Pierce GJ, Santos MB, Hughes S (1997) Species and size differences in the digestion of otoliths and beaks: implications for estimates of pinniped diet composition. Can J Fish Aquat Sci 54: 105-119

Tol lit DJ, Heaslip SG, Barrick RL, Trites AW (2007) Impact of diet-index selection and the digestion of prey hard remains on determining the diet of the Steller sea lion (Eumetopias jubatus). Can J Zool 85:1-15

Tuset VM, Lombarte A, Assis CA (2008) Otolith atlas for the western Mediterranean, north and central eastern Atlantic. Sci Mar 72:7-198

Watt J, Pierce GJ, Boyle PR (1997) Guide to the identification of North Sea fish using premaxillae and vertebrae. ICES Coop Res Rep No. 220. ICES, Copenhagen

Submitted: May 28, 2013; Accepted: December 9, 2013

Proofs received from author(s): March 18, 2014 